This item was submitted to Loughborough's Research Repository by the author.

Items in Figshare are protected by copyright, with all rights reserved, unless otherwise indicated.

\title{
Testing microtubular SOFCs in unmanned air vehicles (UAVs)
}

\section{PLEASE CITE THE PUBLISHED VERSION}

http://dx.doi.org/10.1149/05701.0451ecst

\section{PUBLISHER}

(C) ECS - The Electrochemical Society

\section{VERSION}

VoR (Version of Record)

\section{LICENCE}

CC BY-NC-ND 4.0

\section{REPOSITORY RECORD}

Meadowcroft, Antony D., Simon R. Howroyd, Kevin Kendall, and Michaela Kendall. 2014. "Testing Microtubular Sofcs in Unmanned Air Vehicles (uavs)”. figshare. https://hdl.handle.net/2134/13994. 
This item was submitted to Loughborough's Institutional Repository (https://dspace.lboro.ac.uk/) by the author and is made available under the following Creative Commons Licence conditions.

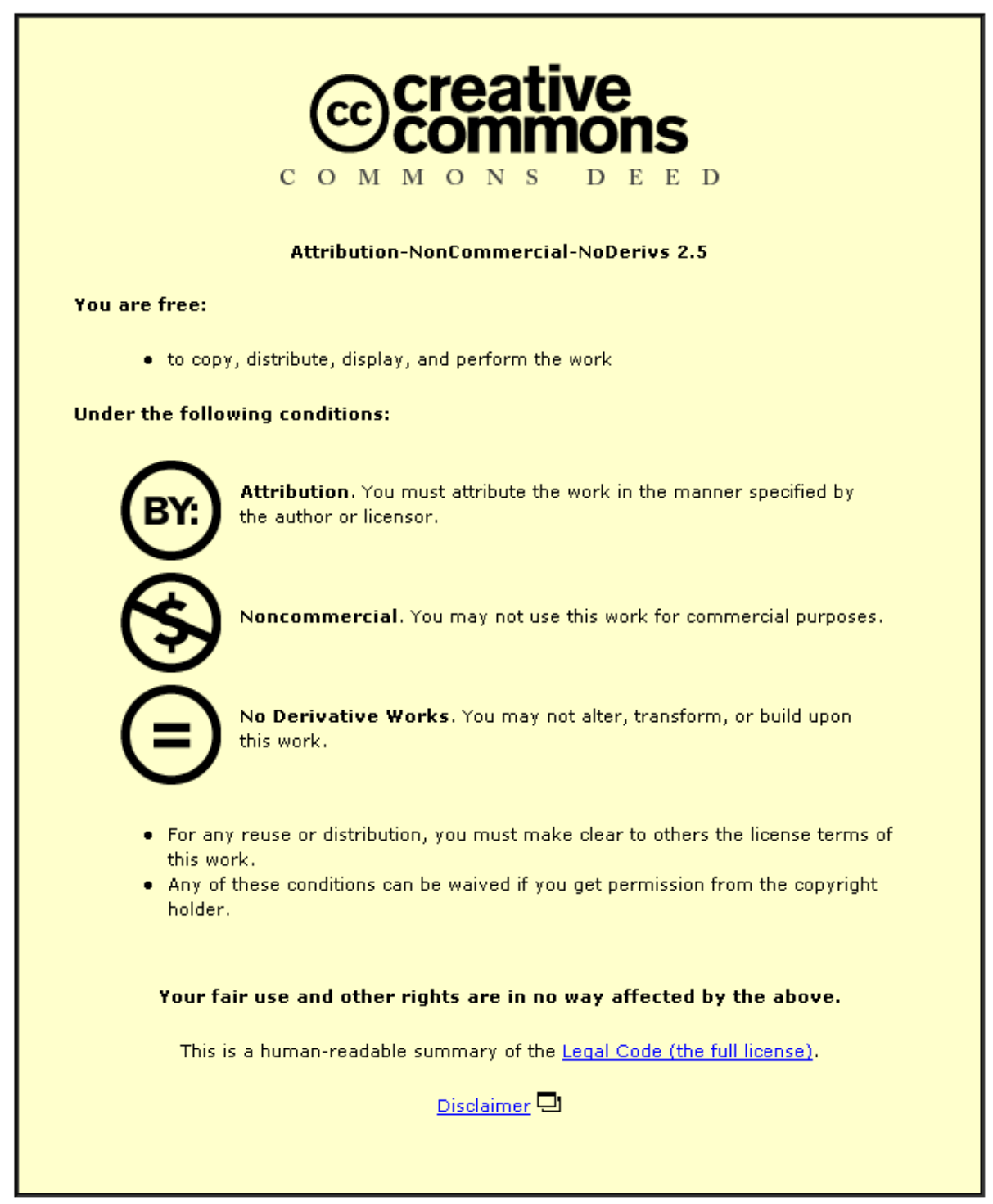

For the full text of this licence, please go to: http://creativecommons.org/licenses/by-nc-nd/2.5/ 


\title{
Testing Microtubular SOFCs in Unmanned Air Vehicles (UAVs)
}

\author{
A. D. Meadowcroft ${ }^{\mathrm{a}}, \mathrm{S} . \mathrm{Howroyd}^{\mathrm{b}}, \mathrm{K} . \mathrm{Kendall}^{\mathrm{c}}$ and M. Kendall ${ }^{\mathrm{c}}$ \\ ${ }^{\text {a }}$ Department of Chemical Engineering, University of Birmingham, Edgbaston, UK \\ ${ }^{\mathrm{b}}$ Department of Aeronautical Engineering, Loughborough University, UK \\ ${ }^{\mathrm{c}}$ Adelan Ltd, Weekin Works, Harborne, UK
}

\begin{abstract}
Unmanned Air Vehicles (UAVs) powered by microtubular SOFCs (mSOFCs) are described for comparison with polymer fuel cells (PEFCs). Using propane as fuel, $7 \mathrm{~mm}$ diameter $\mathrm{mSOFCs}$ have been tested in a $2 \mathrm{~m}$ wingspan aircraft with a total weight of $6 \mathrm{~kg}$. The start-up time was 12 minutes to deliver $250 \mathrm{~W}$ in a fuel cell/battery hybrid drive system. Tubes were YSZ cermet anode supported, with $10 \mu \mathrm{m} \mathrm{YSZ}$ electrolyte, $6 \mu \mathrm{m}$ SDC interlayer coated with $50 \mu \mathrm{m}$ LSCF cathode. Silver wires were used as interconnects. Pure propane fuel gas was mixed with air in a CPOX reactor using catalytic fuel processing mesh. A polymeric fuel inlet manifold gave cold sealing at the tube inlet ends which projected out of the hot box. Cathode air was provided in counterflow, preheated over an anode off-gas catalyst. The fuel utilization was $55 \%$, output power of $250 \mathrm{~W}$. The fuel cell was incorporated in a hybrid electrical system with lithium polymer battery and inserted in a Skywalker X8 UAV with $500 \mathrm{~g}$ of propane in an aluminum tank.
\end{abstract}

\section{Introduction}

Solid Oxide Fuel Cells (SOFCs) should be better than Polymer Electrolyte Fuel Cells (PEFCs) in Unmanned Air Vehicles (UAVs). The reason is that propane in an aluminium container has a much better energy storage density than hydrogen gas in a pressurized cylinder used in PEFCs. But SOFCs require heavy ceramic membranes plus thermal insulation not necessary in the PEFC system. Therefore it is essential to consider how the SOFC can be improved to compete better with PEFCs in UAVs. This paper studies microtubular SOFCs assembled into a system weighing $2.5 \mathrm{~kg}$ and tests this in a $2 \mathrm{~m}$ wingspan UAV with a total mass of $6 \mathrm{~kg}$.

A number of companies including Protonex and Horizon have developed portable PEFC units which have been tested in UAVs, especially with hydrides as the fuel storage medium. Switching to methanol to replace compressed hydrogen, direct methanol fuel cells (DMFCs) have been utilized in an array of applications from soldier portable battery chargers, to recreational vehicle power packs marketed by SFC Power. SOFC has also seen the transition to portable power with Ultra-AMI, Adelan, Acumentrics, Ezelleron and other companies developing portable products. The key question is how these SOFC designs can compete with PEFCs in the UAV space. 
With a large military and civilian market, there has been much effort to develop fuel cell powered UAVs. A recent survey has shown that by the end of 2011 there was data available on at least 36 UAVs utilizing fuel cells (1). Of these flying fuel cells, the power ranged from $10 \mathrm{~W}$ to $1300 \mathrm{~W}$, with the majority using PEFC technology. Ultra-AMI was the main company developing SOFC for UAV applications. We investigate how the microtubular SOFC concept utilized by Ultra-AMI can be further advanced by considering improvements in materials and design.

\section{Microtubular SOFCs (mSOFCs)}

mSOFCs, invented between 1992 and 1994 (2), offer key advantages over planar SOFCs for use in UAVs. The tubes display simple sealing and offer thermal shock resistance much greater than in planar SOFCs (3). The tubular design also uses silver wires instead of heavy bipolar plates, making systems much lighter by comparison. These weight reduction parameters allow mSOFC to out-compete PEFC systems in terms of system gravimetric power density in all but the shortest of flight times, as shown in Figure 1.

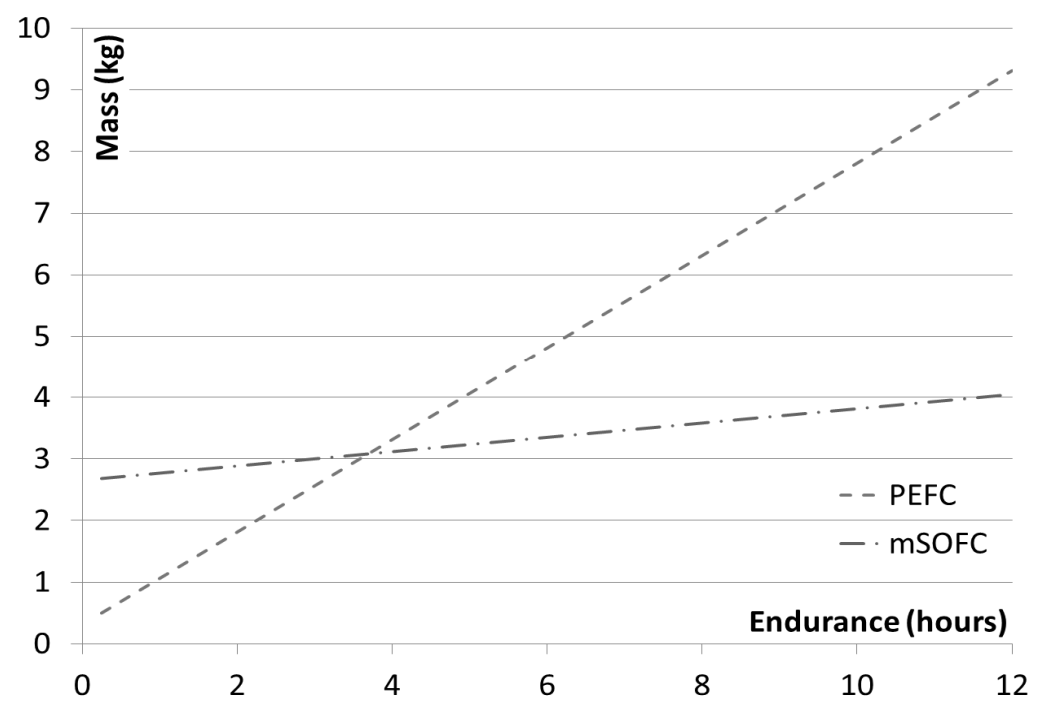

Figure 1. Mass of fuel cell system as a function of endurance, based on a $250 \mathrm{~W}$ system with PEFC fuelled by 700 bar $\mathrm{H} 2$ and $\mathrm{mSOFC}$ fuelled by liquid propane in aluminum assuming $25 \%$ total efficiency (4-7).

$\underline{\text { Cells }}$

The mSOFC cells were Yttria Stabilized Zirconia(YSZ)/nickel cermet anode supported, with $10 \mu \mathrm{m}$ YSZ electrolyte, $6 \mu \mathrm{m}$ SDC interlayer coated with $50 \mu \mathrm{m}$ LSCF cathode. Current collection points were created through a layer of porous silver ink over the cathode, the anode current collection points being created through removal of a ring of electrolyte to expose the anode material beneath. This ring was painted with a dense silver ink to reduce hydrogen leaks. $1 \mathrm{~mm}$ Silver wire was used as an interconnect. This was held in place using twined $0.35 \mathrm{~mm}$ silver wire on the cathode. On the anode a ring of silver wire was placed over the dense ink before cementing in place. 
In order to produce consistent and robust connections, interconnects were applied in a two-step process, with anode connections being applied to the tubes ex-situ, and connection to the cathode made in-situ. This approach also ensures that the assembled stack fits its manifolds, as there is no risk of mis-measuring interconnect wires. An added benefit of adding the cathode interconnect in situ comes from the fact that cells will not be moved once secured into the manifold. This securing ensures that the cells will not move in respect to each other, and thus no mechanical stress will be placed on the current collector. Mechanical stresses on the cathode current collector are a leading source of cell failure, as the contact between wire and cell surface becomes compromised.

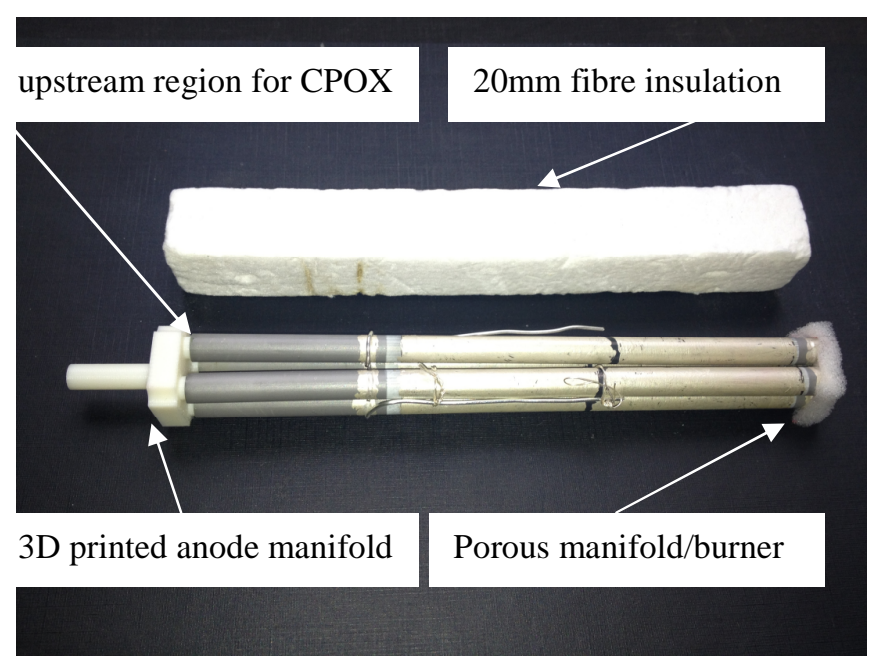

Figure 2. Model stacking of mSOFCs showing the lightweight 3D printed manifold for propane/air mixtures and lightweight porous burner integrated in the exit manifold.

Cells prepared in this configuration were capable of delivering power densities of $0.28 \mathrm{Wcm}^{-2}$ at $0.7 \mathrm{~W}$, translating to power above $5.4 \mathrm{~W}$ per tube. In small scale experiments power densities of $0.4 \mathrm{Wcm}^{-2}$ have been observed. Achieving this on full scale experiments remains a primary focus of our research.

The substacks have been designed with a low volume in mind. Spacing between tubes has been optimized not for effective fluid flow, but for minimum inter-tube gap. A spacing of $3 \mathrm{~mm}$ between tubes in a square array allows space for the use of $1 \mathrm{~mm} \mathrm{Ag}$ wire as a current collector and also for the ceramic glue that hold the connection in place, whilst still maintaining a high volumetric and gravimetric stack power density, $270 \mathrm{Wl}^{-1}$ and $350 \mathrm{Wkg}^{-1}$. The system components then reduced the overall system power density to $100 \mathrm{Wkg}^{-1}$.

\section{$\underline{\text { Manifolds }}$}

For avionic applications weight is of upmost importance. In order to reduce the mass of the stack, novel manifolding techniques were explored. Of note is the use of additive layer manufacture (3D printing). One of the key benefits of mSOFCs is their ability to withstand large temperature gradients without being damaged through thermal stress (3). To the end user this is most noticeable in terms of startup time, especially in small diameter tubes. Kendall has shown that low diameter tubes are able to generate electricity, from cold, in 10s, once sufficient heat has been injected into the tubes to overcome 
thermal inertia (8). As well as being able to withstand rapid heating, the tubes are also able to withstand thermal gradients along the length of the tube, making cold manifolds possible. Cells with a working temperature of $750^{\circ} \mathrm{C}$ are able to protrude through the thermal insulation for anode gas connection at ambient temperature. At this low temperature, gas sealing is simple, reliable and inexpensive. Whilst the present 3D printing material of choice, $\mathrm{ABS}$ is not able to withstand temperatures of more than $100^{\circ} \mathrm{C}$, the possibility of using temperature resistant polymers in future is interesting.

The use of 3D printed ABS achieved a two-fold weight reduction. Firstly, ABS is lighter than either high-temperature metals or ceramic; for example the manifolding shown in Figure 2 gave a weight saving of over $70 \%$. Secondly, the volume of insulation needed is much reduced, as the protruding fuel cell tubes can remain quite warm.

\section{Fuel and Fuel Processing}

The SOFC carries on board a tank of liquid propane, $99.5 \%$ pure and sulfur free, offering an energy density 6 times greater than pressurized hydrogen. The stack itself is fuelled by catalytically-partially-oxidized (CPO) propane. Using a sulfur free fuel removes the need for desulphurization, and therefore reduces weight on the UAV. Whilst odor free fuel is not readily available to the general public, we foresee the use of deodorizing cartridges between the primary fuel tank and the on board fuel storage. This offers an advantage over PEFC as the ground fuel storage tank will be filled with an odorized fuel, increasing safety for the end user.

Pre-reformers run at temperatures approaching $700^{\circ} \mathrm{C}$ for effective conversion from propane to reformate. In the design of Figure 2, the CPOX catalyst is placed inside each tube just upstream of the electrodes within the anode gas stream. Utilization of a catalytically coated support housed within the tubes saves the system from the additional weight implications of a pre-reformer, adding only $30 \mathrm{~g}$ to a stack compared to several $100 \mathrm{~g}$ for a separate reformer. The catalyst becomes active at $700^{\circ} \mathrm{C}$, meaning it must be placed within the hot zone of the cell, immediately before the cathode. The in tube reformer behaves exactly as a separate pre-reformer would. However some control is lost, as reformer temperature cannot be monitored in each tube. Instead a representative tube must be selected to control temperature for the entire stack fuel flow. At the anode exit, where the anode off-gas is combusted, porous support material weighing $20 \mathrm{~g}$ have been demonstrated for use as integrated stack support and afterburners.

\section{$\underline{\text { Balance of Plant BoP }}$}

The balance of plant components need to be kept as small and as light as possible. Gas regulators and flow controllers in particular are extremely heavy on a bench scale, and must be replaced with smaller, better designed devices.

Stack insulation is another key consideration and we have already shown that cold manifolds and in-tube reforming can reduce insulation volume. Our studies show that for application as a product where surfaces should not be hot to the touch, conventional insulation is unsuitable for small UAV's. Microtherm for example would have to be $50 \mathrm{~mm}$ thick to prevent surface temperatures from exceeding $70^{\circ} \mathrm{C}$, with a stack operating at $750^{\circ} \mathrm{C}$. Such insulation would have a mass over $1 \mathrm{~kg}$ for a stack of this size. Air-flow 
over the insulation surface to provide cooling and some heat recuperation is an obvious way to keep the insulation thin.

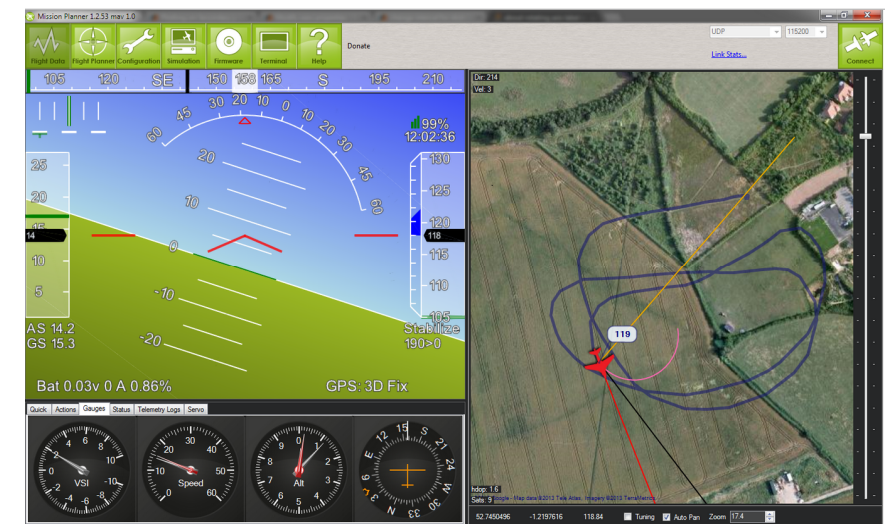

Figure 3. Real time telemetry and path plotting results

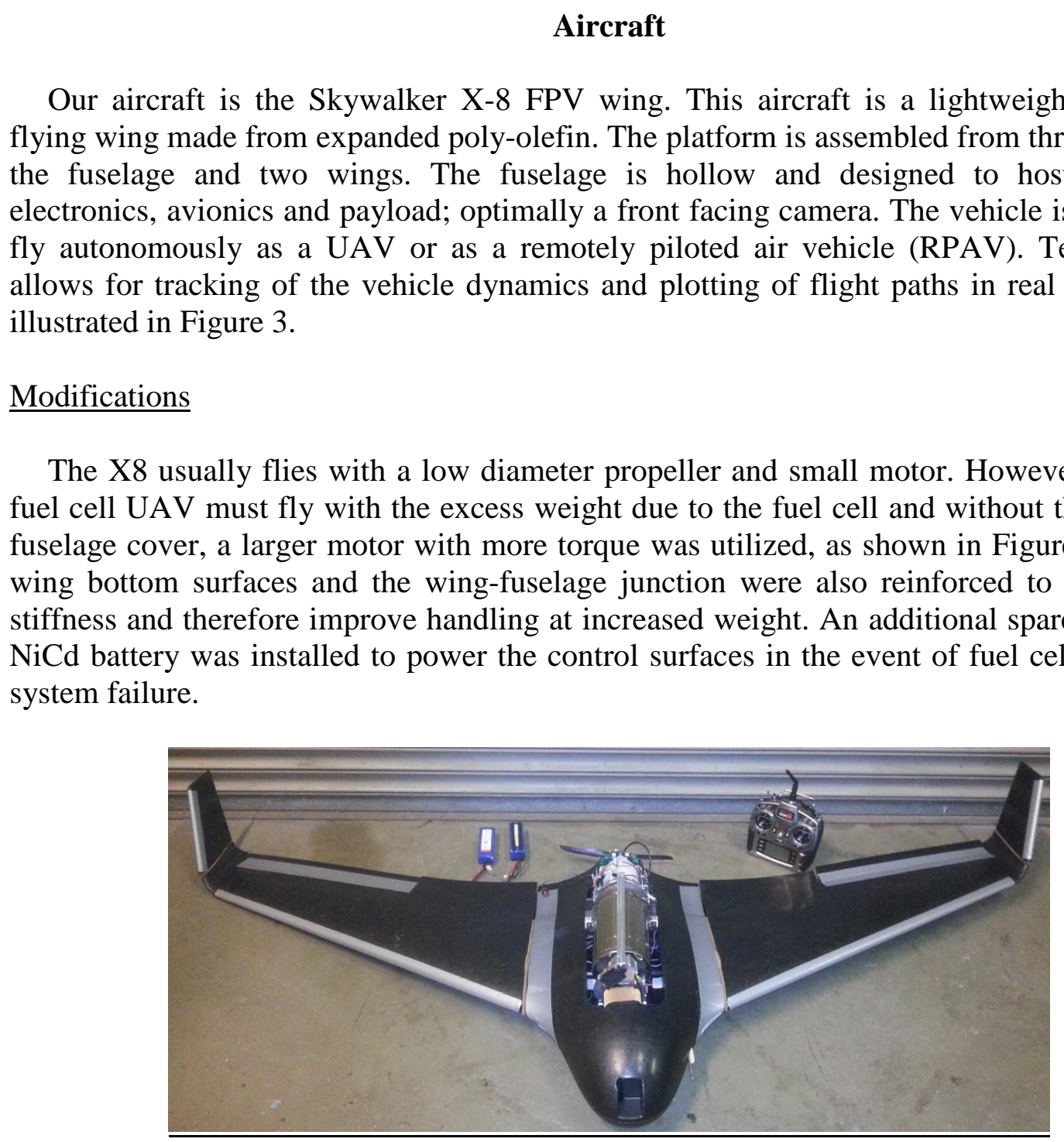

Figure 4. $2 \mathrm{~m}$ wingspan X-8 Aircraft featuring mSOFC system, controller and hybrid batteries. 


\section{Mission Objectives}

Many suggested applications of UAVs would be greatly enhanced with increased endurance. These applications range from search and rescue to surveying power lines and traffic monitoring. Our sample mission was a simple operation, where takeoff and climb were high in energy cost, whilst cruise and landing required little power. The fuel cell was designed to be used in a hybrid drive system with a battery, and was therefore sized smaller than the requirements for climb, as LiPo batteries were able to provide the instantaneous power to accelerate the aircraft rapidly to flight speed from a hand launch to lift the aircraft, and the fuel cell served to provide energy a little over the cruise requirement. In this configuration the fuel cell can be seen as a battery charger. A hybrid system such as this is able to save cost and mass since a smaller fuel cell can be used than if all power was supplied from the stack. In addition the UAV maintains reliability because it can still fly and land on the batteries alone if fuel cell failure occurs. In the case of fuel cell failure, the UAV may return to base for a controlled recovery, reducing losses in the field. Figure 5 shows a typical mission result in which the information on throttle, power, voltage and current was collected by telemetry from the aircraft.
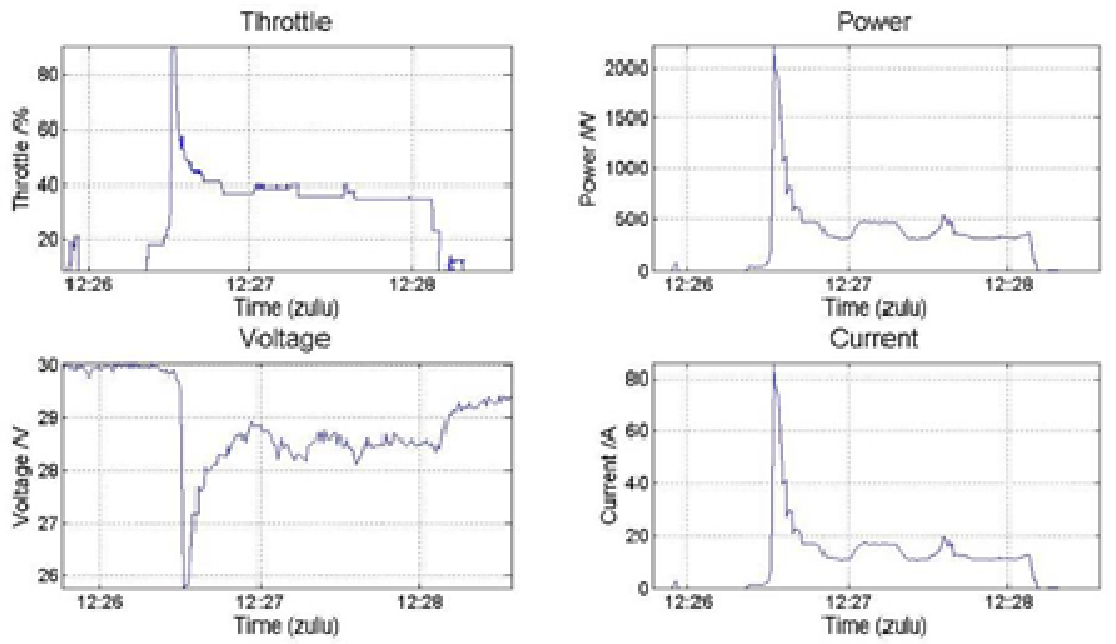

Figure 5. Results from a typical mission where the cruise power was about $300 \mathrm{~W}$

\section{Conclusions}

PEFC and SOFC are competing as power supplies/battery chargers in the UAV market. Although SOFC development has lagged behind PEFC until now, it has the potential to surpass PEFC systems due to the energy density of liquid propane.

We have shown that the SOFC system for UAVs can be tested and improved in several respects.

1. mSOFC cells and systems now perform at a level appropriate for UAV applications.

2. There is a trade-off between microtube diameter and number of interconnections in the system.

3. Stack components (e.g. manifolds) can be enhanced through new techniques like $3 \mathrm{D}$ printing. 
4. Fuel processing by CPO is successful and lightweight, at the cost of system efficiency.

5. mSOFC system power density can be improved through use of lighter insulation.

\section{Acknowledgments}

Thanks are due to TSB for funding this project Number 720029. We also acknowledge the SUAV project 278629 funded by FCH-JU for many useful discussions on these topics. We also acknowledge Kiran Gulia of the IRC in Materials processing at the University of Birmingham, for her assistance in 3D printing.

\section{References}

1. K.S. Howe, PhD Thesis, University of Birmingham, to be published, (2013).

2. S.C. Singhal, K. Kendall, High Temperature SOFCs, Elsevier Science, Oxford 2003 ch.8.

3. K. Kendall, G. Sales, A rapid heating ceramic fuel cell, in Ceramics in Energy Applications, Institute of Energy, London pp.55-63 (1994).

4. US Department of energy website, Status of Hydrogen Storage Technologies, http://www1.eere.energy.gov/hydrogenandfuelcells/storage/tech_status.html

5. Heatgear website, Fuel stick data sheet, www.heatgear.dk

6. Magdalena Dudek, Piotr Tomczyk1, Piotr Wygonik, Mariusz Korkosz, Piotr Bogusz and Bartłomiej Lis Int. J. Electrochem. Sci., 8, 8442 (2013)

7. AMI website, www.ultra-ami.com

8. K Kendall, and A Meadowcroft, , Int J Hydrogen Energy,1725 (2013). 